\title{
Development of an Artificial Neural Network Model to Minimize Power Consumption in the Milling of Heat-Treated and Untreated Wood
}

\author{
Şükrü ÖZŞAHINN ${ }^{1}$, Hilal SINGER ${ }^{2 *}$ \\ ${ }^{1}$ Karadeniz Technical University, Department of Industrial Engineering, Trabzon, TURKEY \\ ${ }^{2}$ Bolu Abant Izzet Baysal University, Department of Industrial Engineering, Bolu, TURKEY \\ *Corresponding author: hilal.singer@hotmail.com
}

Received Date: 24.01.2019

Accepted Date: 24.09.2019

\begin{abstract}
Aim of study: The power consumption of machining operations is an important part of the total production cost. Therefore, in this study, an artificial neural network (ANN) model was developed to model the effects of treatment, rotation speed, cutting depth, and feed rate on power consumption in the wood milling process.
\end{abstract}

Material and methods: A multilayer feed-forward ANN was employed for the prediction of power consumption. The accuracy of the model was assessed by performance indicators such as MAPE, RMSE, and $\mathrm{R}^{2}$.

Main results: It has been observed that the ANN model yielded very satisfactory results with acceptable deviations. The MAPE, RMSE, and $\mathrm{R}^{2}$ values were obtained as $7.533,0.027$, and $0.9737 \%$, respectively, in the testing phase. Furthermore, it was found that power consumption decreased with decreasing of feed rate and cutting depth.

Research highlights: The findings of this study can be used effectively in the forest industry to reduce the experimental time and costs.

Keywords: Artificial Neural Network, Milling, Power Consumption, Wood

\section{Isıl İşlem Uygulanmış ve Uygulanmamış Odunun \\ Frezelenmesinde Güç Tüketimini Azaltmak için Bir Yapay Sinir Ağı Modelinin Geliştirilmesi}

$\ddot{O} \mathbf{z}$

Çalışmanın amacı: İşleme operasyonlarının güç tüketimi toplam üretim maliyetinin önemli bir parçasıdır. Bu nedenle, bu çalışmada odun frezeleme işleminde muamele, dönme hızı, kesme derinliği ve besleme hızının güç tüketimi üzerine olan etkilerini modellemek için bir yapay sinir ağı (YSA) modeli geliştirilmiştir.

Materyal ve yöntem: İleri beslemeli çok katmanlı bir YSA güç tüketimini tahmin etmek için kullanılmıştır. Modelin doğruluğu, MAPE, RMSE ve $\mathrm{R}^{2}$ gibi performans göstergeleri aracıllğıyla değerlendirilmiştir.

Sonuçlar: YSA modelinin kabul edilebilir sapmalarla oldukça tatmin edici neticeler elde ettiği görülmüş̧ür. MAPE, RMSE ve $\mathrm{R}^{2}$ değerleri, test aşamasında sırasıyla \% 7.533, 0.027 ve 0.9737 olarak elde edilmiştir. Ayrıca, besleme hızının ve kesme derinliğinin azalması ile güç tüketiminin azaldığı bulunmuştur.

Araştırma vurguları: Bu çalışmanın bulguları orman endüstrisinde deneysel zamanı ve maliyetleri azaltmak için etkili bir şekilde kullanılabilir.

Anahtar kelimeler: Yapay Sinir Ağı, Frezeleme, Güç Tüketimi, Odun 


\section{Introduction}

Heat treatment is one of the modification methods used to improve the various properties of wood. Heat treatment of wood is an eco-friendly alternative method for wood preservation (Mazela, Zakrzewski, Grześkowiak, Cofta \& Bartkowiak, 2004; Younsi, Kocaefe, Poncsak \& Kocaefe, 2010). The heat treatment temperature generally varies from $120^{\circ} \mathrm{C}$ to $250^{\circ} \mathrm{C}$, and the duration spans between $15 \mathrm{~min}$ and $24 \mathrm{~h}$ (Bakar, Hiziroglu \& Tahir, 2013). Heating the wood at high temperatures reduces shrinkingswelling characteristics, decreases equilibrium moisture content, and increases the weather resistance of a final product (Yildiz, Gezer \& Yildiz, 2006; Kocaefe, Shi, Yang \& Bouazara, 2008). Changes in the properties of wood affect the performance of machining processes. One of the factors that should be considered when evaluating the performance of machining processes is power consumption.

The power consumption, often referred as the cutting power, represents the mechanical work at processing released per second (Ispas, Gurau, Campean, Hacibektasoglu \& Racasan, 2016). Reducing power consumption in wood machining increases energy efficiency and reduces operating costs. Therefore, determining the suitable combinations of parameters that affect power consumption in wood machining is necessary (Tiryaki, Malkoçoğlu \& Özşahin, 2016). Milling is one of the wood machining processes. A large number of factors affect power consumption during the milling of wood. The most important main factors influencing the outcome are wood properties and milling parameters (Sedleckỳ \& Gašparík 2017). Therefore, it is important to evaluate subfactors related to both wood properties and milling parameters for the reduction of power consumption in the wood milling process.

In order to examine the influences of various factors on the power consumption of wood machining processes, many experimental studies have been conducted so far. Stewart (1974) claimed that power consumption increased with increasing of feed rate and cutting depth in planing. Aguilera and Martin (2001) reported that increased cutting depth led to higher power consumption. Rousek and Kopecký (2005) noted that the power increases proportionally with tool speed. Barcík, Kminiak, Řehák and Kvietková (2010) investigated the influences of cutting speed, rake angle, false heartwood, and feed rate on power consumption in the plain milling of beech wood. They noted that power consumption increases with increasing of feed rate and cutting speed. Salca (2015) reported that the best results were obtained with decreasing of feed rate.

From the experimental studies conducted, it is clear that plenty of values for factors have to be investigated to detect a change in power consumption. However, conducting comprehensive experiments causes high costs and the loss of much time. Changes in power consumption can be described using data modeling methods. Hence, the number of tests required for investigating the influences of factors on power consumption can be decreased. Furthermore, the performance of machining processes can be evaluated by conducting less number of experimental investigations. One of the most popular modeling methods is the artificial neural network (ANN). The reason for its popularity lies in the fact that it can define complex and nonlinear relationships among variables without any prior knowledge of the handled problem (Rumbayan, Abudureyimu \& Nagasaka, 2012; Ozsahin, 2013).

The ANN approach plays a significant role in engineering applications. This approach has been widely employed in the field of wood science, for example in analyzing moisture in wood (Avramidis \& Wu, 2007), predicting fracture toughness (Samarasinghe, Kulasiri \& Jamieson, 2007), classifying veneer defects (Castellani \& Rowlands, 2008), wood recognition (Khalid, Lee, Yusof \& Nadaraj, 2008), modeling of drying characteristics of wood (Ceylan, 2008), optimization of process parameters in oriented strand board manufacturing (Özşahin, 2012; Ozsahin, 2013), modeling of some mechanical properties of wood and wood-based materials (Tiryaki \& Hamzaçebi, 2014; Tiryaki, Aras, Kalaycıoglu, Erişir \& Aydın, 2017a), and modeling of some physical properties of heattreated wood (Ozsahin \& Murat, 2018). However, the limited information is available on predicting the power consumption of wood 
machining processes. Tiryaki et al. (2016) designed a neural network model to predict power consumption in wood planing. In another study, Tiryaki, Özşahin and Aydın (2017b) used ANNs to predict power consumption in the abrasive machining of wood.

Consequently, the literature review has revealed that the ANN approach has been widely utilized to solve problems in many fields of wood science. However, this approach has not yet been employed to model the influences of treatment, rotation speed, cutting depth, and feed rate on power consumption in the machining of wood or wood-based materials. Therefore, the aim of the current study is to develop an ANN model for modeling the influences of the aforementioned parameters on power consumption in the wood milling process.

\section{Materials and Methods \\ Experimental Procedure}

The data used in this study were taken from Ispas et al. (2016). Namely, the present study does not conduct the experiments for determining the influences of treatment, rotation speed, cutting depth, and feed rate on power consumption in the wood milling process. Instead, it aims at predicting the influences of the aforementioned variables on power consumption using the data obtained from the experimental results of Ispas et al. (2016). Some experimental details were explained below.

Beech wood (Fagus sylvatica L.) was selected as the material of the experiments. A total of 60 samples of beech wood with dimensions of $400 \mathrm{~mm} \times 50 \mathrm{~mm} \times 28 \mathrm{~mm}$ were prepared for the experiments. Half of the samples were heat-treated at $200{ }^{\circ} \mathrm{C}$ for $2.5 \mathrm{~h}$. The untreated and heat-treated samples were conditioned at $20{ }^{\circ} \mathrm{C}$ and $55 \%$ relative humidity for 4 weeks. The moisture content of the untreated samples was $8 \pm 0.5 \%$ and that of the treated samples was $3 \pm 0.2 \%$. In the milling of the samples, two different levels of rotation speed (3300 and $4818 \mathrm{rpm}$ ), five different levels of feed rate $(4.5,9,13.5,18$, and $22.5 \mathrm{~m} / \mathrm{min}$ ) and three different levels of cutting depth $(1,2$, and $3 \mathrm{~mm})$ were chosen as milling conditions. The samples were processed on the vertical milling machine type
MNF10. The cutting power consumption was computed using Eq. (1).

$$
P=P_{t}-P_{0}
$$

In Eq. (1), $P$ is the cutting power consumption $(\mathrm{kW}), P_{t}$ is the total power consumption $(\mathrm{kW})$, and $P_{0}$ is the power consumed by the device during the idle run $(\mathrm{kW})$. A three-phase transducer was used to measure $P_{t}$ and $P_{0}$.

\section{Artificial Neural Networks}

ANNs are computational models inspired by structure or functional aspects of biological nervous systems (Chandwani, Agrawal \& Nagar, 2015). The ANN approach offers many advantages over traditional statistical methods because it is capable of learning complicated and nonlinear relations among variables (Kiani Deh Kiani, Ghobadian, Tavakoli, Nikbakht \& Najafi, 2010; Atici 2011; Choudhury, Hosseinzadeh \& Berndt, 2012). ANNs can be utilized for many applications such as nonlinear function estimation, data sorting, pattern recognition, optimization, clustering, and simulation (Yadav and Chandel, 2014).

The multilayer perceptron (MLP) is the most commonly used ANN type (Guresen, Kayakutlu \& Daim, 2011). The MLP structure consists of one input layer, one output layer, and $t$ intermediate (hidden) layers (Koçer, 2010). The input layer takes data, the hidden layer(s) processes them, and the output layer displays the outputs of the network (Canakci, Özşahin \&Varol, 2012).

The layers of the MLP network consist of processing units (neurons). The neurons of a layer are linked to the neurons of neighboring layers with weights (Özşahin, 2012). An artificial neuron $(j)$ gets input signals $\left(x_{i}\right)$, and then each input signal is multiplied by the connection weight $\left(w_{i j}\right)$. The net input $\left(\right.$ net $\left._{j}\right)$ is obtained by the sum of the relevant bias $\left(\theta_{j}\right)$ and weighted signals. Outputs $\left(y_{j}\right)$ are calculated by applying a mathematical function $(f()$.$) to net j$. This process is summarized in equations (2) and (3), and illustrated in Figure 1 (Ozsahin, 2013). 


$$
\text { net }_{j}=\sum_{i=1}^{n} x_{i} w_{i j}-\theta_{j}
$$

$$
y_{j}=f\left(\text { net }_{j}\right)
$$

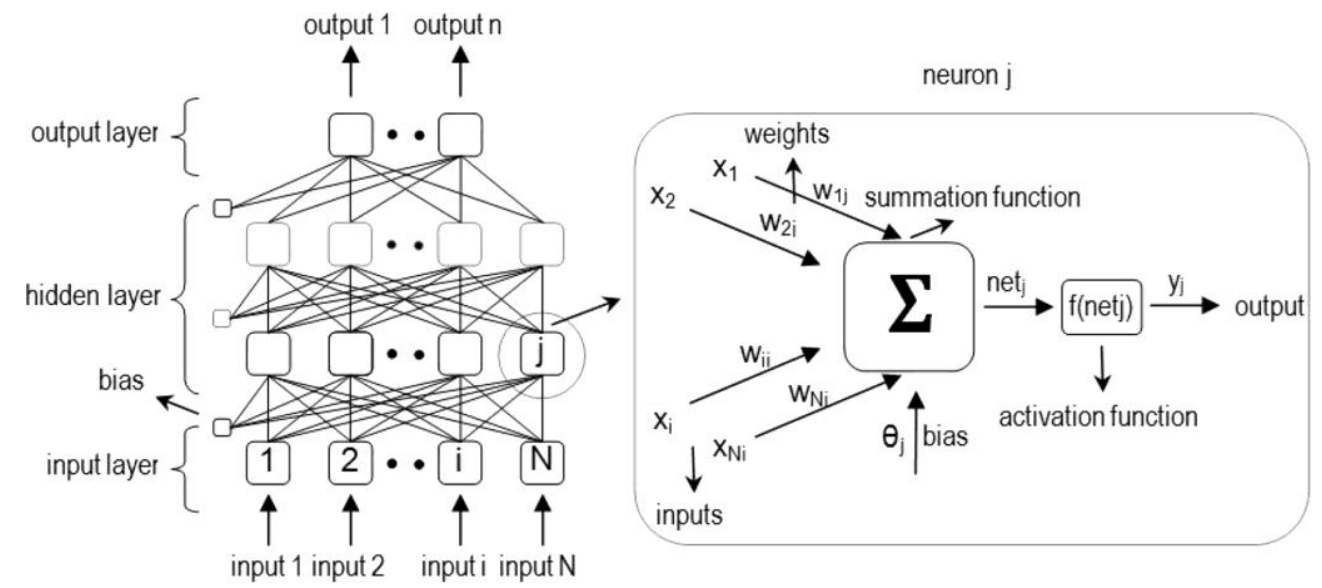

Figure 1. A schematic illustration of ANN

The main phases of ANNs are training and testing. During the training process, inputs and outputs are presented to the network. An iterative algorithm adjusts the values of weights and biases of the network so that ANN outputs can be as close as possible to desired outputs. The adjusting operation is repeated until the maximum epoch is exceeded or the error falls below a determined value. Once the training of ANNs is completed, the trained model is tested using unseen data sets. If the model performance is high, the values of weights and biases are saved. These weights and biases can be employed to predict outputs for new input vectors (Yildirim, Özşahin \& Akyüz, 2011).

Determining the optimal network architecture is one of the main tasks. Input neurons and output neurons represent inputs and outputs, respectively. However, the number of hidden neurons is mostly detected by the trial-and-error method (Kalteh, 2013). If the number of hidden neurons is less than the optimal value, the network will be unable to learn complex relationships among variables. On the other hand, too many hidden neurons can lead to overfitting (Hamzehie, Fattahi, Najibi, Van der Bruggen \& Mazinani, 2015). It is hard to detect the most suitable network, even for a skilled user (Ma, Zeng, Tian, Sun \& Zhou, 2012).

\section{Artificial Neural Networks Analysis}

In the present study, the effects of treatment, rotation speed, cutting depth, and feed rate on power consumption in the wood milling process were modeled via ANNs. The data $(60$ samples) were obtained from the experimental results of Ispas et al. (2016). The codes required for the ANN analysis were written in MATLAB.

Within the model, four input variables were defined as treatment, rotation speed, cutting depth, and feed rate. Power consumption was considered as the output variable of the model. The data division process was carried out after determining the input and output variables. In this process, the available data are commonly partitioned into training, validation, and testing sets (Csábrági, Molnár, Tanos \& Kovács, 2017). Therefore, the data set of this study was randomly divided into three sections containing training, validation, and testing sets comprised of 40 (66.66\% of the data), 10 (16.67\% of the data), and $10(16.67 \%$ of the data) samples, respectively. Different data groups were constituted, and each data group was tested to detect suitable data sets. Tables 1-3 show the data sets used in the ANN analysis.

Normalizing the data before the training, validating, and testing of ANNs is recommended to equalize the significance of variables. In this study, all of the variables were mapped to the $\left[\begin{array}{ll}-1 & 1\end{array}\right]$ interval. With the help of a reverse normalizing process, the 
model outputs were converted into the original values. The normalization was performed using equation (4). In this equation, $X_{n o r m}$ is the normalized value, $X$ is the real

$$
X_{\text {norm }}=2 \times \frac{X-X_{\min }}{X_{\max }-X_{\min }}-1
$$
value, and $X_{\min }$ and $X_{\max }$ are the minimum and maximum values of $X$, respectively.

Table 1. Experimental data, predicted values, and percentage errors for the training set

\begin{tabular}{|c|c|c|c|c|c|c|}
\hline \multirow{2}{*}{ Treatment } & \multirow{2}{*}{$\begin{array}{l}\text { Rotation speed } \\
\qquad(\mathrm{rpm})\end{array}$} & \multirow{2}{*}{$\begin{array}{l}\text { Cutting depth } \\
(\mathrm{mm})\end{array}$} & \multirow{2}{*}{$\begin{array}{c}\text { Feed rate } \\
(\mathrm{m} / \mathrm{min})\end{array}$} & \multicolumn{3}{|c|}{ Power consumption (kW) } \\
\hline & & & & Actual & Predicted & Error $(\%)$ \\
\hline Untreated & 3300 & 1 & 9 & 0.09 & 0.09 & 1.18 \\
\hline Untreated & 3300 & 1 & 13.5 & 0.17 & 0.18 & -6.46 \\
\hline Untreated & 3300 & 1 & 18 & 0.27 & 0.25 & 8.62 \\
\hline Untreated & 3300 & 2 & 4.5 & 0.10 & 0.12 & -20.07 \\
\hline Untreated & 3300 & 2 & 18 & 0.40 & 0.40 & -0.89 \\
\hline Untreated & 3300 & 2 & 22.5 & 0.47 & 0.46 & 1.77 \\
\hline Untreated & 3300 & 3 & 4.5 & 0.18 & 0.18 & -0.18 \\
\hline Untreated & 3300 & 3 & 9 & 0.24 & 0.25 & -2.73 \\
\hline Untreated & 3300 & 3 & 13.5 & 0.43 & 0.42 & 1.73 \\
\hline Untreated & 3300 & 3 & 22.5 & 0.59 & 0.58 & 2.01 \\
\hline Untreated & 4818 & 1 & 4.5 & 0.09 & 0.08 & 5.56 \\
\hline Untreated & 4818 & 1 & 13.5 & 0.20 & 0.21 & -6.59 \\
\hline Untreated & 4818 & 1 & 18 & 0.29 & 0.28 & 1.84 \\
\hline Untreated & 4818 & 1 & 22.5 & 0.35 & 0.35 & 1.12 \\
\hline Untreated & 4818 & 2 & 9 & 0.22 & 0.21 & 6.18 \\
\hline Untreated & 4818 & 2 & 13.5 & 0.36 & 0.36 & -0.65 \\
\hline Untreated & 4818 & 2 & 18 & 0.45 & 0.44 & 1.90 \\
\hline Untreated & 4818 & 3 & 4.5 & 0.22 & 0.20 & 8.00 \\
\hline Untreated & 4818 & 3 & 9 & 0.25 & 0.27 & -6.48 \\
\hline Untreated & 4818 & 3 & 22.5 & 0.59 & 0.60 & -1.25 \\
\hline Heat-Treated & 3300 & 1 & 4.5 & 0.06 & 0.05 & 9.62 \\
\hline Heat-Treated & 3300 & 1 & 13.5 & 0.09 & 0.10 & -16.25 \\
\hline Heat-Treated & 3300 & 1 & 18 & 0.14 & 0.14 & -1.91 \\
\hline Heat-Treated & 3300 & 1 & 22.5 & 0.18 & 0.18 & -1.12 \\
\hline Heat-Treated & 3300 & 2 & 4.5 & 0.10 & 0.11 & -9.04 \\
\hline Heat-Treated & 3300 & 2 & 9 & 0.16 & 0.16 & 0.60 \\
\hline Heat-Treated & 3300 & 2 & 13.5 & 0.19 & 0.19 & 0.92 \\
\hline Heat-Treated & 3300 & 2 & 18 & 0.22 & 0.22 & -1.34 \\
\hline Heat-Treated & 3300 & 3 & 13.5 & 0.24 & 0.25 & -2.46 \\
\hline Heat-Treated & 3300 & 3 & 18 & 0.26 & 0.27 & -4.67 \\
\hline Heat-Treated & 3300 & 3 & 22.5 & 0.30 & 0.31 & -2.26 \\
\hline Heat-Treated & 4818 & 1 & 9 & 0.09 & 0.09 & -1.71 \\
\hline Heat-Treated & 4818 & 1 & 18 & 0.15 & 0.14 & 3.43 \\
\hline Heat-Treated & 4818 & 1 & 22.5 & 0.18 & 0.18 & -0.34 \\
\hline Heat-Treated & 4818 & 2 & 4.5 & 0.11 & 0.11 & 4.08 \\
\hline Heat-Treated & 4818 & 2 & 9 & 0.19 & 0.18 & 3.40 \\
\hline Heat-Treated & 4818 & 2 & 22.5 & 0.31 & 0.31 & 0.55 \\
\hline Heat-Treated & 4818 & 3 & 4.5 & 0.12 & 0.13 & -10.03 \\
\hline Heat-Treated & 4818 & 3 & 9 & 0.24 & 0.24 & -1.25 \\
\hline Heat-Treated & 4818 & 3 & 13.5 & 0.29 & 0.30 & -2.84 \\
\hline
\end{tabular}


Table 2. Experimental data, predicted values, and percentage errors for the validation set

\begin{tabular}{ccccccc}
\hline Treatment & $\begin{array}{c}\text { Rotation speed } \\
(\mathrm{rpm})\end{array}$ & $\begin{array}{c}\text { Cutting depth } \\
(\mathrm{mm})\end{array}$ & $\begin{array}{c}\text { Feed rate } \\
(\mathrm{m} / \mathrm{min})\end{array}$ & & \multicolumn{2}{c}{ Power consumption $(\mathrm{kW})$} \\
\cline { 5 - 7 } & 3300 & 1 & 22.5 & 0.32 & 0.31 & 4.17 \\
Untreated & 3300 & 2 & 9 & 0.23 & 0.20 & 15.05 \\
Untreated & 3300 & 3 & 18 & 0.49 & 0.54 & -9.46 \\
Untreated & 4818 & 2 & 4.5 & 0.13 & 0.13 & -1.05 \\
Untreated & 4818 & 3 & 13.5 & 0.41 & 0.43 & -3.73 \\
Untreated & 48.5 & 9 & 0.08 & 0.08 & 1.12 \\
Heat-Treated & 3300 & 1 & 4.5 & 0.12 & 0.13 & -7.20 \\
Heat-Treated & 3300 & 3 & 13.5 & 0.11 & 0.12 & -7.63 \\
Heat-Treated & 4818 & 1 & 18 & 0.30 & 0.27 & 10.25 \\
Heat-Treated & 4818 & 2 & 22.5 & 0.44 & 0.39 & 11.94 \\
Heat-Treated & 4818 & 3 & & & &
\end{tabular}

Table 3. Experimental data, predicted values, and percentage errors for the testing set

\begin{tabular}{ccccccc}
\hline \multirow{2}{*}{ Treatment } & $\begin{array}{c}\text { Rotation speed } \\
(\mathrm{rpm})\end{array}$ & $\begin{array}{c}\text { Cutting depth } \\
(\mathrm{mm})\end{array}$ & $\begin{array}{c}\text { Feed rate } \\
(\mathrm{m} / \mathrm{min})\end{array}$ & & \multicolumn{2}{c}{ Power consumption $(\mathrm{kW})$} \\
\hline Untreated & 3300 & 1 & 4.5 & 0.06 & 0.07 & -10.73 \\
Untreated & 3300 & 2 & 13.5 & 0.32 & 0.33 & -1.74 \\
Untreated & 4818 & 1 & 9 & 0.13 & 0.12 & 10.14 \\
Untreated & 4818 & 2 & 22.5 & 0.50 & 0.50 & 0.84 \\
Untreated & 4818 & 3 & 18 & 0.49 & 0.56 & -13.41 \\
Heat-Treated & 3300 & 2 & 22.5 & 0.24 & 0.27 & -12.14 \\
Heat-Treated & 3300 & 3 & 9 & 0.20 & 0.22 & -8.01 \\
Heat-Treated & 4818 & 1 & 4.5 & 0.05 & 0.05 & 3.04 \\
Heat-Treated & 4818 & 2 & 13.5 & 0.22 & 0.23 & -5.90 \\
Heat-Treated & 4818 & 3 & 18 & 0.38 & 0.34 & 9.38 \\
\hline
\end{tabular}

In modeling, a multilayer feed-forward ANN was employed. The activation functions were selected as the hyperbolic tangent sigmoid function and the linear transfer function. The training algorithm was the Levenberg-Marquardt algorithm. The gradient descent with a momentum backpropagation algorithm was used as the learning rule. The performance function was the mean square error (MSE) [equation (5)].

$$
\mathrm{MSE}=\frac{1}{N} \sum_{i=1}^{N}\left(t_{i}-t d_{i}\right)^{2}
$$

Here, $t_{i}$ is the real value, $t d_{i}$ is the model output, and $N$ is the number of observations.
The performance of each ANN model is strongly dependent on the devised structure of the network (Betiku \& Taiwo 2015). The parameters such as the number of hidden layers and hidden neurons, transfer functions, and the training algorithm affect the performance of the network (Quan, Zou, Wang, Liu \& Li, 2017). In this study, the optimum network parameters were detected by employing the trial-and-error approach. Different ANN structures and parameters were tried to minimize the difference between the measured and predicted outputs. As a result of the training period, the optimum values of weights and biases of the ANN model were obtained. The values of them can be seen from Table 4 .

Table 4. The optimum values of weights and biases

\begin{tabular}{ccccccccccc}
\hline \multicolumn{4}{c}{ Hidden layer 1 } & \multicolumn{4}{c}{ Hidden layer 2 } & \multicolumn{3}{c}{ Output layer } \\
\hline Neuron 1 & Neuron 2 & Neuron 3 & Bias 1 & Neuron 1 Neuron 2 Neuron 3 Neuron 4 & Bias 2 & Neuron 1 & Bias 3 \\
\hline 2.56496 & 0.11876 & 1.15039 & -2.14499 & 1.83196 & 1.34668 & 0.37894 & 0.42338 & -1.95351 & -0.23066 & -0.23554 \\
-0.45017 & -0.02565 & -0.10277 & 0.40495 & 1.79231 & 2.79025 & 0.79849 & -2.45322 & -0.36604 & -0.43584 & - \\
0.42144 & -0.20710 & -0.78664 & 1.81620 & 0.51177 & 1.22424 & -1.15257 & 0.66680 & 2.12557 & -0.34748 & - \\
-0.58188 & -0.15586 & 2.01293 & - & - & - & - & - & 1.02449 & 1.01377 & - \\
\hline
\end{tabular}


The ANN model producing the nearest values to the experimental results was selected to make predictions. The network established in this study is composed of four layers and two of them are hidden layers. The input and output layers of the network consists of four and one neurons, respectively. The first hidden layer has three neurons and the second hidden layer has four neurons. The architecture of the proposed network is presented in Figure 2.

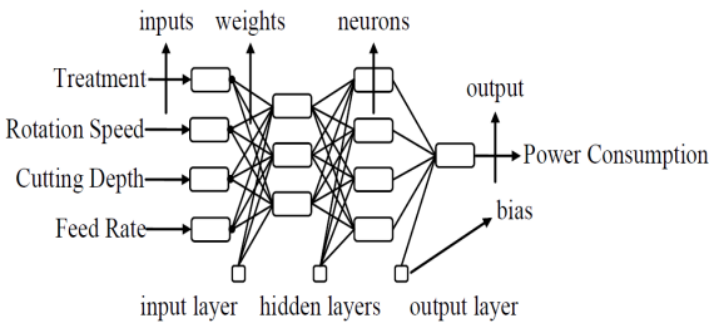

Figure 2. The ANN architecture of the prediction model

The validity of the prediction model was evaluated by employing the following indicators: the mean absolute percentage error (MAPE), the root mean square error (RMSE), and the coefficient of determination $\left(\mathrm{R}^{2}\right)$. MAPE and RMSE demonstrate the degree of the deviation of predicted values from actual values. Therefore, the values of MAPE and RMSE must be as small as possible. The higher $\mathrm{R}^{2}$ implies a high similarity between actual values and ANN outputs. The MAPE, RMSE, and $\mathrm{R}^{2}$ values were computed using equations (6), (7), and (8), respectively.

$$
\begin{gathered}
\text { MAPE }=\frac{1}{N}\left(\sum_{i=1}^{N}\left[\left|\frac{t_{i}-t d_{i}}{t_{i}}\right|\right]\right) \times 100 \\
\mathrm{RMSE}=\sqrt{\frac{1}{N} \sum_{i=1}^{N}\left(t_{i}-t d_{i}\right)^{2}} \\
\mathrm{R}^{2}=1-\frac{\sum_{i=1}^{N}\left(t_{i}-t d_{i}\right)^{2}}{\sum_{i=1}^{N}\left(t_{i}-\bar{t}\right)^{2}}
\end{gathered}
$$

where $\bar{t}$ is the average of model outputs.

\section{Results and Discussion}

In this study, power consumption values were predicted by ANNs. The data were divided into three groups: (1) the training set to adjust the values of weights and biases, (2) the validation set to monitor model performance, and (3) the testing set to evaluate the generalization capability of the model. The number of hidden layers and their neurons was detected by comparing the performance of the tried networks. As a result of the analysis, an ANN structure containing three and four neurons in the hidden layers was chosen as the prediction model.

The ANN model was trained, validated, and tested with the help of 60 data. Figure 3 shows the error variation graphic of the chosen neural network. As seen in this figure, the performance function reached the minimum value $(0.010442)$ at the end of 16 epochs.

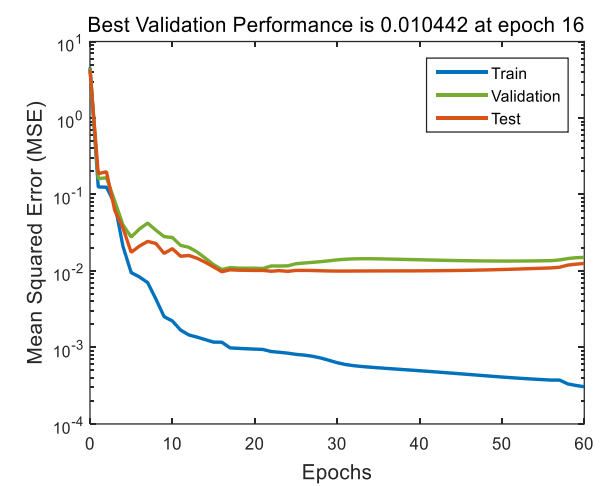

Figure 3. Variations of the MSE

The model results are given in Tables 1-3. From these tables, it is possible to see that the outputs computed by employing the ANN model are very close to the actual outputs.

The validity range of the developed model for the training, validation, and testing processes can be seen from Table 1, Table 2, and Table 3, respectively. As stated before, MAPE and RMSE were employed to compare the established models. A model giving the lower values of MAPE and RMSE should be selected to make predictions (Küçükönder, Boyac1 \& Akyüz, 2016). When Table 5 is examined, it is seen that the prediction results were found with very low errors. The MAPE values are $4.075 \%$ for the training data set, $7.160 \%$ for the validation data set, and $7.533 \%$ for the testing data set. In previous 
studies, it was stated that the MAPE $\leq 10 \%$ indicates high prediction accuracy (Lewis 1982; Aydin, Karakurt \& Hamzacebi, 2014; Tiryaki et al., 2017a). Namely, the MAPE results of the developed model are within acceptable accuracy ranges. From Table 5, it is possible to see that the RMSE values are $0.009,0.028$, and 0.027 for training, validation, and testing, respectively. The low values of MAPE and RMSE indicates that the prediction model could be employed to optimize the performance of the milling process.

Table 5. The MAPE, RMSE, and $\mathrm{R}^{2}$ results

\begin{tabular}{cccc}
\hline \multirow{2}{*}{ Data set } & \multicolumn{3}{c}{ Performance criterion } \\
\cline { 2 - 4 } & MAPE & RMSE & $\mathrm{R}^{2}$ \\
\hline Training & 4.075 & 0.009 & 0.9947 \\
Validation & 7.160 & 0.028 & 0.9658 \\
Testing & 7.533 & 0.027 & 0.9737 \\
\hline
\end{tabular}

The regression analysis is often performed to evaluate the accuracy of networks. A $\mathrm{R}^{2}$ value closer to 1 indicates an excellent match between measured and predicted outputs ( $\mathrm{Wu}$, Huang, Schmalz \& Fohrer, 2014). The correlations between the real and predicted outputs are presented in Figure 4 . The $\mathrm{R}^{2}$ values are $0.9947,0.9658$, and 0.9737 for training, validation, and testing, respectively. The value of $\mathrm{R}^{2}$ in the testing set indicates that the network explains at least $97.37 \%$ of the actual data. This result supports the applicability of the prediction model to predict power consumption in milling.

The comparative plots of the actual and predicted values are presented in Figure 5. As seen in this figure, the values are very close to each other. This situation enhances the applicability of the ANN model.

Neural network models can compute intermediate values for an optimization study (Varol, Canakçı \& Özşahin, 2013). In other words, well-trained ANNs can provide untested experimental results. The impacts of process parameters on power consumption can be investigated for numerous combinations. In this optimization study, treatment and rotation speed were fixed as untreated and $4060 \mathrm{rpm}$, respectively, and the effect of cutting depth and feed rate on power consumption was predicted. Furthermore, in another trial, treatment and rotation speed were fixed as heat-treated and $4060 \mathrm{rpm}$, respectively, and cutting depth and feed rate were changed. The intermediate values were obtained by the model for different feed rates and cutting depths, and are presented in Figure 6 . The optimization of power consumption values can be performed via an analysis of responses of the model.

(a)

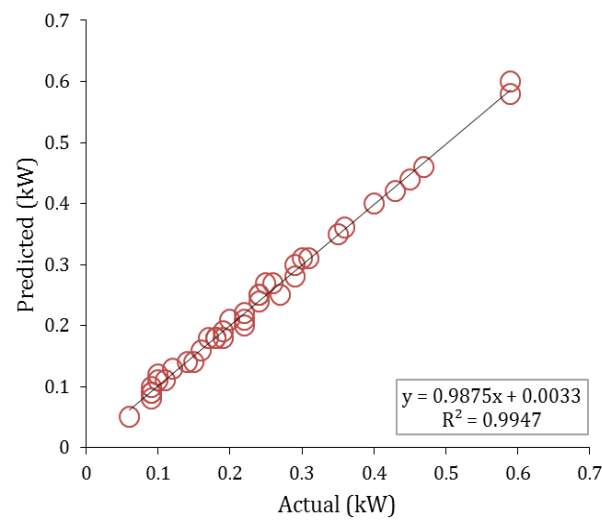

(b)

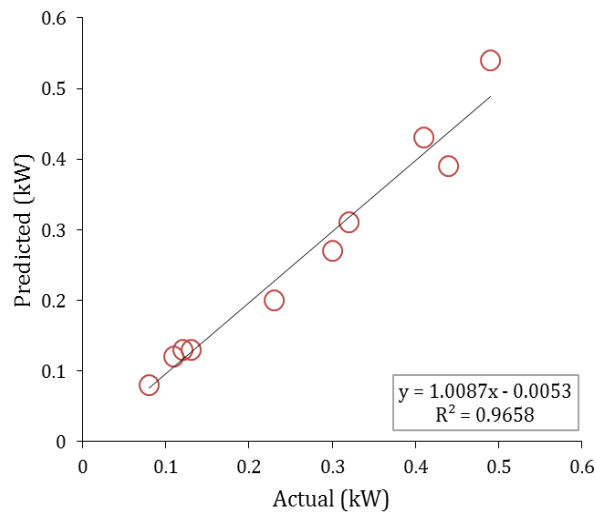

(c)

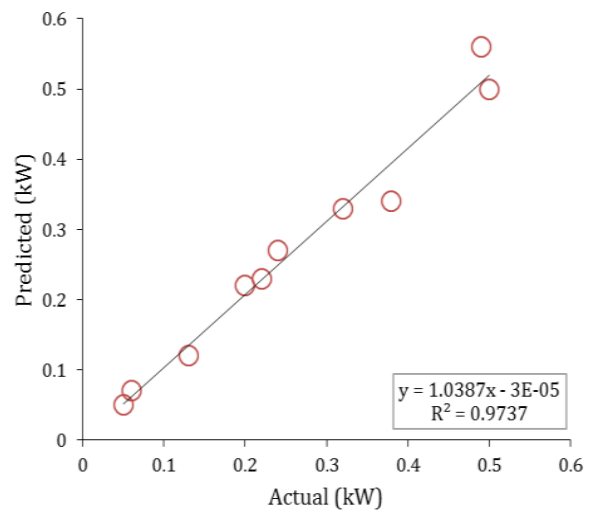

Figure 4. The relationship between the measured and predicted values: (a) training, (b) validation, and (c) testing 
(a)

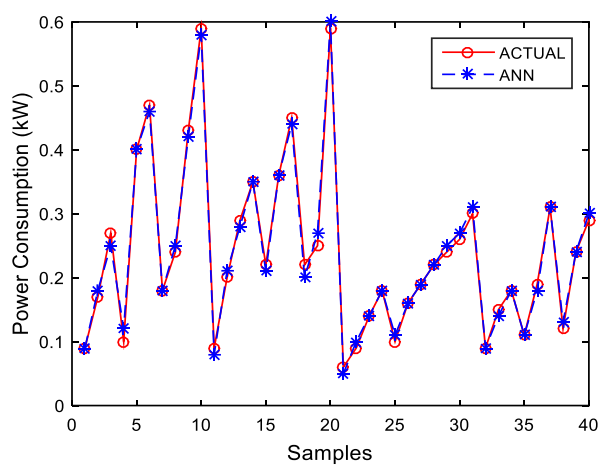

(b)

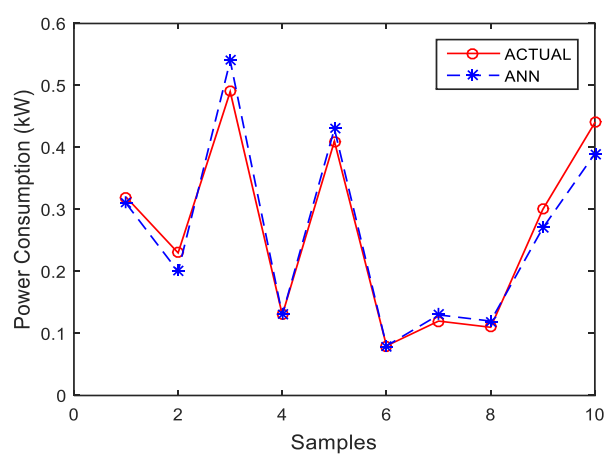

(c)

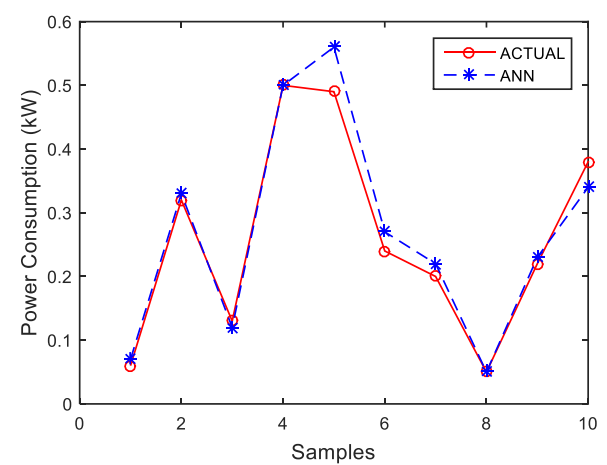

Figure 5. The comparison of the measured and predicted values: (a) training, (b) validation, and (c) testing

As seen in Figure 6, power consumption decreases with decreasing of cutting depth and feed rate. Many researchers reported the influences of cutting depth and feed rate on power consumption in wood machining, and the results demonstrated that power consumption increases with an increase in cutting depth and feed rate (Stewart 1974; Aguilera \& Martin 2001; Salca 2015). The feed of the material that must be taken off within the same time unit increases with increasing of feed rate. This situation leads to higher power consumption (Barcík et al., 2010).
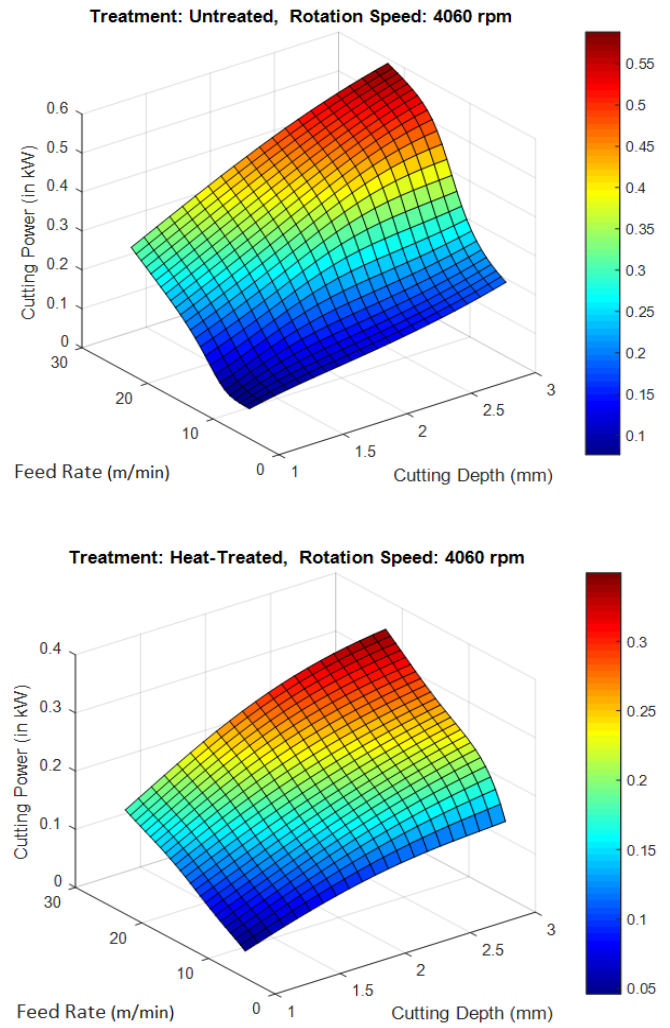

Figure 6. The changes in power consumption for different feed rates and cutting depths

The modeling results show that there is a good agreement between the model outputs and the experimental results. Moreover, the developed model is able to predict the intermediate values with an acceptable accuracy. Thanks to the findings of this study, the power consumption of the wood milling process can be determined in a short period of time with low error rates. Consequently, the present study may be useful for the forest industry to eliminate time-consuming experimental investigations.

\section{Conclusion}

This work focused on predicting the influences of treatment, rotation speed, cutting depth, and feed rate on power consumption in the wood milling process by means of ANNs. In order to determine the best topology, various accuracy analyses were carried out using the data obtained from the literature. The ANN model with the 4-3-4-1 structure was the best one for predicting the power consumption of the wood milling process. 
The predicted values showed a close match with the measured values. The performance of the model was acceptable with MAPE = $7.533 \%, \mathrm{RMSE}=0.027$, and $\mathrm{R}^{2}=0.9737$ for the testing period. Furthermore, this study predicted the intermediate power consumption values. Better results were obtained with decreasing of feed rate and cutting depth.

Consequently, the ANN approach is a successful tool for predicting the power consumption of the wood milling process. The influences of factors on power consumption could be predicted by ANNs without the need for an extra experiment. In further research, different variables can be used to predict power consumption.

\section{Acknowledgements}

The authors would like to thank Mihai Ispas, Lidia Gurau, Mihaela Campean, Murat Hacibektasoglu, and Sergiu Racasan for providing the data used in this paper.

\section{References}

Aguilera, A. \& Martin, P. (2001). Machining qualification of solid wood of Fagus silvatica L. and Picea excelsa L.: cutting forces, power requirements and surface roughness. Holz als Roh- und Werkstoff, 59(6), 483-488.

Atıc1, U. (2011). Prediction of the strength of mineral admixture concrete using multivariable regression analysis and an artificial neural network. Expert Systems with Applications, 38(8), 9609-9618.

Avramidis, S. \& Wu, H. (2007). Artificial neural network and mathematical modeling comparative analysis of nonisothermal diffusion of moisture in wood. Holz als Rohund Werkstoff, 65, 89-93.

Aydın, G., Karakurt, I. \& Hamzacebi, C. (2014). Artificial neural network and regression models for performance prediction of abrasive waterjet in rock cutting. International Journal of Advanced Manufacturing Technology, 75(912), 1321-1330.

Bakar, B. F. A., Hızıroğlu, S. \& Md Tahir, P. (2013). Properties of some thermally modified wood species. Materials and Design, 43, 348355.

Barcík, Š., Kminiak, R., Řehák, T. \& Kvietková, M. (2010). The influence of selected factors on energy requirements for plain milling of beech wood. Journal of Forest Science, 56(5), 243250.
Betiku, E. \& Taiwo, A.E. (2015). Modeling and optimization of bioethanol production from breadfruit starch hydrolyzate vis-à-vis response surface methodology and artificial neural network. Renewable Energy, 74, 87-94.

Canakçı, A., Özsahin, S. \& Varol, T. (2012). Modeling the influence of a process control agent on the properties of metal matrix composite powders using artificial neural networks. Powder Technology, 228, 26-35.

Castellani, M. \& Rowlands, H. (2008). Evolutionary feature selection applied to artificial neural networks for wood-veneer classification. International Journal of Production Research, 46(11), 3085-3105.

Ceylan, İ. (2008). Determination of drying characteristics of timber by using artificial neural networks and mathematical models. Drying Technology, 26(12), 1469-1476.

Chandwani, V., Agrawal, V. \& Nagar, R. (2015). Modeling slump of ready mix concrete using genetic algorithms assisted training of Artificial Neural Networks. Expert Systems with Applications, 42(2), 885-893.

Choudhury, T.A., Hosseinzadeh, N. \& Berndt, C. C. (2012). Improving the generalization ability of an artificial neural network in predicting inflight particle characteristics of an atmospheric plasma spray process. Journal of Thermal Spray Technology, 21(5), 935-949.

Csábrági, A., Molnár, S., Tanos, P. \& Kovács, J. (2017). Application of artificial neural networks to the forecasting of dissolvedoxygen content in the Hungarian section of the river Danube. Ecological Engineering, 100, 63-72.

Güresen, E., Kayakutlu, G. \& Daim, T. U. (2011). Using artificial neural network models in stock market index prediction. Expert Systems with Applications, 38(8), 10389-10397.

Hamzehie, M.E., Fattahi, M., Najibi, H., Van der Bruggen, B. \& Mazinani, S. (2015). Application of artificial neural networks for estimation of solubility of acid gases (H2S and $\mathrm{CO} 2)$ in 32 commonly ionic liquid and amine solutions. Journal of Natural Gas Science and Engineering, 24, 106-114.

Ispas, M., Gurau, L., Campean, M., Hacibektasoglu, M. \& Racasan, S. (2016). Milling of heat-treated beech wood (Fagus sylvatica L.) and analysis of surface quality. BioResources, 11(4), 9095-9111.

Kalteh, A.M. (2013). Monthly river flow forecasting using artificial neural network and support vector regression models coupled with wavelet transform. Computers \& Geosciences, $54,1-8$.

Khalid, M., Lee, E.L.Y., Yusof, R. \& Nadaraj, M. (2008). Design of an intelligent wood species 
recognition system. International Journal of Simulation: Systems, Science and Technology, 9(3), 9-19.

Kiani Deh Kiani, M., Ghobadian, B., Tavakoli, T., Nikbakht, A.M. \& Najafi, G. (2010). Application of artificial neural networks for the prediction of performance and exhaust emissions in SI engine using ethanol-gasoline blends. Energy, 35(1), 65-69.

Kocaefe, D., Shi, J.L., Yang, D.Q. \& Bouazara, M. (2008). Mechanical properties, dimensional stability, and mold resistance of heat-treated jack pine and aspen. Forest Products Journal, 58(6), 88-93.

Koçer, S. (2010). Classifying myopathy and neuropathy neuromuscular diseases using artificial neural networks. International Journal of Pattern Recognition and Artificial Intelligence, 24(5), 791-807.

Küçükönder, H., Boyac1, S. \& Akyüz, A. (2016). A modeling study with an artificial neural network: developing estimation models for the tomato plant leaf area. Turkish Journal of Agriculture and Forestry, 40(2), 203-212.

Lewis, C.D. (1982). International and business forecasting methods. London: Butter-worths.

Ma, X., Zeng, W., Tian, F., Sun, Y. \& Zhou, Y. J. (2012). Modeling constitutive relationship of BT25 titanium alloy during hot deformation by artificial neural network. Journal of Materials Engineering and Performance, 21(8), 15911597.

Mazela, B., Zakrzewski, R., Grześkowiak, W., Cofta, G. \& Bartkowiak, M. (2004). Resistance of thermally modified wood to basidiomycetes. Wood Technology, 7(1), 253-262.

Özşahin, Ş. (2012). The use of an artificial neural network for modeling the moisture absorption and thickness swelling of oriented strand board. BioResources, 7(1), 1053-1067.

Özşahin, Ş. (2013). Optimization of process parameters in oriented strand board manufacturing with artificial neural network analysis. European Journal of Wood and Wood Products, 71(6), 769-777.

Özşahin, Ş. \& Murat, M. (2018). Prediction of equilibrium moisture content and specific gravity of heat treated wood by artificial neural networks. European Journal of Wood and Wood Products, 76(2), 563-572.

Quan, G.Z., Zou, Z.Y., Wang, T., Liu, B. \& Li, J.C. (2017). Modeling the hot deformation behaviors of as-extruded 7075 aluminum alloy by an artificial neural network with backpropagation algorithm. High Temperature Materials and Processes, 36(1), 1-13.

Rousek, M. \& Kopecký, Z. (2005). Monitoring of power consumption in high-speed milling.
Drvna Industrija, 56(3), 121-126.

Rumbayan, M., Abudureyimu, A. \& Nagasaka, K. (2012). Mapping of solar energy potential in Indonesia using artificial neural network and geographical information system. Renewable and Sustainable Energy Reviews, 16(3), 14371449.

Salca, E. A. (2015). Optimization of wood milling schedule - A case study. Pro Ligno, 11(4), 525530.

Samarasinghe, S., Kulasiri, D. \& Jamieson, T. (2007). Neural networks for predicting fracture toughness of individual wood samples. Silva Fennica, 41(1), 105-122.

Sedleckỳ, M. \& Gašparík, M. (2017). Power consumption during edge milling of mediumdensity fiberboard and edge-glued panel. BioResources, 12(4), 7413-7426.

Stewart, H.A. (1974). Comparison of factors affecting power for abrasive and knife planing of hardwoods. Forest Products Journal, 24(3), 31-34.

Tiryaki, S. \& Hamzaçebi, C. (2014). Predicting modulus of rupture (MOR) and modulus of elasticity (MOE) of heat treated woods by artificial neural networks. Measurement, 49, 266-274.

Tiryaki, S., Aras, U., Kalaycıŏ̆lu, H., Erişir, E. \& Aydin, A. (2017a). Predictive models for modulus of rupture and modulus of elasticity of particleboard manufactured in different pressing conditions. High Temperature Materials and Processes, 36(6), 623-634.

Tiryaki, S., Malkoçoğlu, A. \& Özşahin, Ş. (2016). Artificial neural network modeling to predict optimum power comsumption in wood machining. Drewno, 59(196), 109-125.

Tiryaki, S., Özşahin, Ş. \& Aydın, A. (2017b). Employing artificial neural networks for minimizing surface roughness and power consumption in abrasive machining of wood. European Journal of Wood and Wood Products, 75(3), 347-358.

Varol, T., Canakçı, A. \& Özşahin, S. (2013). Artificial neural network modeling to effect of reinforcement properties on the physical and mechanical properties of Al2024-B4C composites produced by powder metallurgy. Composites: Part B, 54, 224-233.

Wu, N., Huang, J., Schmalz, B. \& Fohrer, N. (2014). Modeling daily chlorophyll a dynamics in a German lowland river using artificial neural networks and multiple linear regression approaches. Limnology, 15(1), 47-56.

Yadav, A. K. \& Chandel, S. S. (2014). Solar radiation prediction using artificial neural network techniques: A review. Renewable and Sustainable Energy Reviews, 33, 772-781. 
Yıldırım, I., Özşahin, S. \& Akyüz, K. C. (2011). Prediction of the financial return of the paper sector with artificial neural networks. BioResources, 6(4), 4076-4091.

Yildiz, S., Gezer, E. D. \& Yildiz, U. C. (2006). Mechanical and chemical behavior of spruce wood modified by heat. Building and Environment, 41(12), 1762-1766.

Younsi, R., Kocaefe, D., Poncsak, S. \& Kocaefe, Y. (2010). Computational and experimental analysis of high temperature thermal treatment of wood based on ThermoWood technology. International Communications in Heat and Mass Transfer, 37(1), 21-28. 